Phillips; Honorary Secretary, Prof. J. A. Crowther ; New Members of the Board, Dr. Allan Ferguson and Mr. R. S. Whipple. In pursuance of one of the main objects of the Institute, namely, "to urge the import. ance of Physics in Industry", the Board has decided to arrange a two-day conference in the spring of 1935 on the applications of X-ray structural analysis to various industries. The main function of the conference will be to bring to the notice of industrialists what physics and physicists can do to help industry, rather than the discussion of technical matters among experts. The conference will be held in Manchester in conjunction with the local section of the Institute; and it is proposed to arrange an exhibition and visits in connexion with the meetings. Full details will be announced in due course.

\section{Ancient Chinese Books on Materia Medica}

IN the year A.D. 659, an illustrated volume of materia medica was published in China. It seems to have served until about 1061, when an extensive revision took place. Prof. Manzo Nakao has studied the history of this great compilation ("Notes on Shao-hsing Hsiao-ting Ching-shih Chêng-lei Pei-chi Pên-tsao (The Ancient Chinese Materia Medica Revised in the Sung Dynasty Shao-hsing period, 1131-1162)"'. J. Shanghai Sci. Inst. (3), 1, 1-9, May 1933). Much of the subject matter of the paper is of interest only to the Chinese historian, but some of the descriptions show that the work was very thorough, and covered at least 22 volumes. There were apparently several distinct revisions. The medicines can all be recognised; and the historical investigation was stimulated by the possibility of reviving some of the ancient remedies under modern conditions.

\section{"World List of Scientific Periodicals"}

THE second edition of the "World List of Scientific Periodicals" will be published in one volume by the Oxford University Press on June 30, at the price of $£ 33 s$., but subscribers in advance will receive it at $£ 22 s$. Such subscribers resident in Great Britain or Europe must post their cheques before June 30, or if outside Great Britain or Europe before July 30 . The new edition will contain titles and holdings of periodicals current right up to the end of 1933. The number of libraries the holdings of which are listed has been increased by 39 , the number being 189 as against 150. Approximately 10,000 new titles have been added, the total number of entries amounting to 36,380 . Each entry contains the title and place of publication of the periodical, the abbreviation, and the symbols for the libraries in which it is to be found and the dates of their holdings. Further information can be obtained from the Secretary, "World List of Scientific Periodicals", c/o The Zoological Society of London, Regent's Park, London, N.W.8.

\section{Announcements}

THe annual visitation of the National Physical Laboratory, Teddington, will be held on Tuesday, June 26, at 3-6 p.m.
THE annual visitation of the Royal Observatory, Greenwich, will be held on Saturday, June 2. The new 36 -in. reflecting telescope will be opened by the First Lord of the Admiralty at 3 p.m., and the Observatory will be open for inspection by invited guests at 3.30 p.m.

Prof. Lours Martin has been elected director of the Pasteur Institute of Paris in succession to the late Dr. Roux, with whom he had been closely associated.

Prof. J. BArcroft will deliver the Stephen Paget Memorial Lecture at the annual general meeting of the Research Defence Society at the London School of Tropical Medicine and Hygiene, Keppel Street, W.C.1, on June 5, at 3 p.m. The subject of Prof. Barcroft's lecture will be "Experiments on Man".

THE attention of chemists is directed by the Union Internationale de Chimie to the services rendered by the International Bureau of PhysicoChemical Symbols in placing at their disposal pure organic compounds the constants of which have been determined with great accuracy. The specimens supplied by the Bureau are guaranteed as possessing the constants of the values given in the published proceedings of the Bureau ( $J$. Chim. Phys., vols. $23,25,27,29$ and 31). They can be obtained at cost price from the Secretary of the Bureau, Prof. J. Timmermans, University, Brussels, from whom further information can be obtained.

The McGraw-Hill Publishing Co., Ltd., has issued its catalogue for 1934, containing a classified list of its books on agriculture, zoology and botany. The catalogue can be obtained post free from Aldwych House, London, W.C.2.

Applications are invited for the following appointments, on or before the dates mentioned:-An assistant in the Inquiry Bureau of the Building Research Station, Garston-The Secretary, Department of Scientific and Industrial Research, 16, Old Queen Street, Westminster, S.W.1 (May 30). A professor of botany at the University of St. Andrews -The Registrar (May 31). An assistant keeper of Oriental printed books and MSS. in the India Office Library-The Establishment Officer, India Office, Whitehall, S.W.I (June 1). A lecturer (woman) in mathematics (biology or botany subsidiary), at the Darlington Training College--The Principal (June 4). A lecturer in physics and elementary science at the City of Leeds Training College-The Director of Education, Education Department, Calverley Street, Leeds (June 5). A curator of the Museum and Art Gallery at Barking-The Town Clerk, Town Hall, Barking (June 7). An assistant agricultural organiser to the Northamptonshire County Council-The Secretary for Education, County Education Offices, Northampton (June 9). A professor of electrical technology at the Indian Institute of Science, Bangalore, India-The Director (Aug. I). A University professor of mining at Imperial College of Science and Technology-The Academic Registrar, University of London, S.W.7 (Jan. 14, 1935). 